\title{
ВПЛИВ СПІВАДСОРБОВАНИХ АТОМІВ СТРОНЦЮ НА ПОВЕРХНЕВУ ДИФУЗІЮ У СУБМОНОШАРОВИХ ПЛІВКАХ ЛІТІЮ НА ГРАНІ (112) ВОЛЬФРАМУ
}

\author{
А.Т. ЛОБУРЕЦЬ, ${ }^{1}$ С.О. ЗАЇКА, ${ }^{1}$ А.Г. НАУМОВЕЦЬ ${ }^{2}$ \\ ${ }^{1}$ Полтавський національний технічний університет ім. Ю. Кондратюка \\ (Просп. Першотравневий, 24, Полтава 36011; e-mail: anatollob@gmail. com) \\ 2 Інститут фізики НАН України \\ (Просп. Науки, 46, Київ 03680, Україна)
}

\begin{abstract}
Методом сканувальної контактно-потенціальної мікроскопї досліджено поверхневу дифузію літію у субмоношарових співадсорбованих плівках $\mathrm{Li}-\mathrm{Sr}$ на атомно-анізотропній грані (112) вольфраму. Мета роботи - дослідження впливу сильно зв'язаних і менш рухливих адатомів (Sr) на кінетику дифузії більш рухливих адатомів (Li). Встановлено, що адатоми стронцію сильно пригнічують дифузію літію. Одержано концентраційні залежності хімічних коефіцієнтів дифузії, енергії активації і передекспонентного множника у рівнянні Арреніуса. Розглянуто можливі механізми поверхневої дифузії у співадсорбованій плівці із урахуванням характеру латеральної взаємодії адатомів, яка спричиняє утворення довгоперіодних ланцюжкових структур. Зроблено висновок про те, що зі збільшенням концентрації літію, коли плівка стає структурно несумірною з підкладкою, починають діяти колективні механізми дифузії, які зумовлюють експонентне зростання коефіцієнта дифузіі. Результати можуть бути використані при розробленні технологій модифікації фізико-хімічних властивостей поверхонь.
\end{abstract}

\section{1. Вступ}

Багатокомпонентні адсорбовані моношари є такими особливими об'єктами, фізичні й хімічні властивості яких зумовлюються взаємодією кожного компонента з підкладкою, а також взаємодією між собою адсорбованих частинок (адчастинок) однакової і різної хімічної природи. На практиці найчастіше мають справу саме з багатокомпонентними адсорбційними системами. Нерідко додаванням у моношар навіть незначної кількості домішки можна сильно вплинути на каталітичну активність, роботу виходу, кінетику дифузіі й інші фізико-хімічні характеристики поверхні. Це, з одного боку, дозволяє цілеспрямовано модифікувати поверхню. 3 іншого боку, неконтрольоване осадження домішок на поверхню може приводити до небажаних ефектів.

Слід зазначити, що в різних практичних задачах часто висуваються протилежні вимоги до напрямку модифікації поверхонь. Наприклад, для стимулювання каталітичних реакцій або створення умов для самозбирання моношарів необхідно забезпечувати достатньо високу рухливість адчастинок. На відміну від цього, висока поверхнева рухливість може негативно впливати на стабільність і термін служби нанопристроїв і наноматеріалів.

Очевидно, що комплексне дослідження факторів, що визначають властивості багатокомпонентних адшарів, є досить актуальною проблемою. Дотепер ці фактори вивчені набагато менше, ніж у випадку однокомпонентних моношарів, що зумовлено значно складнішим характером структури багатокомпонентних моношарів і взаємодій у них.

Метою даної роботи є дослідження деяких характеристик поверхневої дифузї в модельній двокомпонентній системі - співадсорбованих плівках літію й стронцію на грані (112) кристала вольфраму. Обидва адсорбати є електропозитивними металами (літій - лужний елемент, стронцій - лужноземельний), але їх атомні радіуси сильно різняться $\left(r_{\mathrm{Li}}=1,55\right.$ $\AA, r_{\mathrm{Sr}}=2,15 \AA$ ). Грань $\mathrm{W}(112)$ має сильно анізотропну структуру, яка утворена щільно упакованими рядами атомів вольфраму й борозенками атомарної глибини, які чергуються між собою (рис. 1). На цій підкладці у попередніх роботах докладно вивчено кінетику поверхневої дифузії літію і стронцію окремо $[1,2]$. Було встановлено, що при однаковій температурі рухливість Li на порядки величини перевищує рухливість атомів Sr. Також отримано деякі попередні дані про те, що присутність на поверхні співадсорбованих атомів $\mathrm{Sr}$ пригнічує рухливість адатомів Li [3]. У цій статті наведено результати більш детального дослідження цього ефекту. Отримано концентраційні залежності коефіцієнтів дифузії літію при трьох різних покриттях стронцію. Визначено залежності від ступеня покриття енергій активації й передекспонентних множників у рівнянні Арреніуса, що 


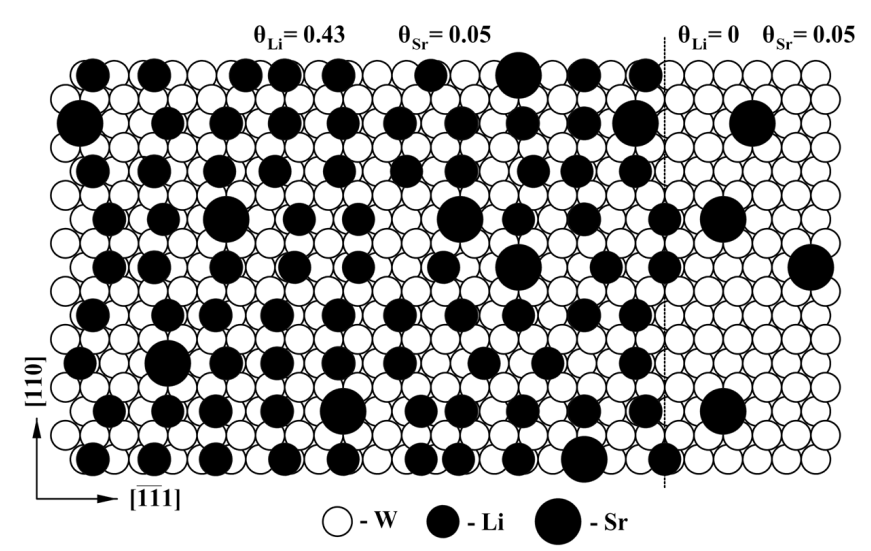

Рис. 1. Схематичне зображення будови грані (112) вольфраму (білі кружки). Малі чорні кружки зображують адсорбовані атоми літію, великі - атоми стронцію. $\theta_{\mathrm{Li}} \approx 0,43, \theta_{\mathrm{Sr}} \approx 0,05$. Край концентраційної сходинки літію позначений праворуч пунктирною лінією. Рисунок зроблено у припущенні, що плівка структурно некогерентна з підкладкою. Далекий порядок відсутній, але наявний орієнтаційний порядок

описує температурну залежність коефіцієнта дифузіі літію.

\section{2. Методи дослідження}

Для дослідження поверхневої дифузії було застосовано метод сканувальної контактно-потенціальної мікроскопії. Це неруйнівний метод, який дозволяє вивчати при різних температурах еволюцію спеціально сформованих концентраційних профілів адсорбату. Локальну концентрацію визначали в результаті сканування поверхні вузьким променем низькоенергетичних електронів для вимірювання залежної від концентрації локальної роботи виходу. Просторова роздільна здатність методу становила $\approx 1$ мкм, а точність визначення ступеня покриття поверхні літієм і стронцієм перебувала в межах 0,01-0,05 моношару. Ступінь покриття поверхні адсорбатом визначаємо як відношення концентрації адатомів до поверхневої концентрації атомів вольфраму, відповідно $\theta_{\mathrm{Li}}=n_{\mathrm{Li}} / n_{W}$ i $\theta_{\mathrm{Sr}}=n_{\mathrm{Sr}} / n_{W}$. За такого визначення покриття, що відповідає $\theta=1$, називають геометричним моношаром. Для грані (112) вольфраму $n_{W}=8,2 \cdot 10^{14} \mathrm{~cm}^{-2}$. Підкреслимо, що в даній роботі всі експерименти виконували при субмоношарових покриттях $(\theta<1)$.

Конструкцію нашої експериментальної установки описано в [4]. Виміри проводили в умовах надвисокого вакууму $\approx 10^{-11}-10^{-12}$ Торр. Підкладкою служила монокристалічна вольфрамова пластинка, тов- щиною 0,07 мм і площею 8·3,2 мм². Точність орієнтації площини поверхні щодо напрямку [112] становила \pm 20 кутових хвилин. Інші деталі експерименту випарники Li i Sr, процедура знегажування кристала вольфраму й видалення з нього вуглецю, методики калібрування атомних пучків Li i Sr, вимірювання роботи виходу, створення концентраційних профілів адсорбатів на поверхні підкладки - описані в наших попередніх роботах $[1,2,5,7]$.

Як відомо, при адсорбції атомів Li i Sr на гранях W робота виходу поверхні зменшується з ростом ступеня покриття на кілька електрон-вольт внаслідок сильної полярності адсорбційного зв'язку. Це дає можливість, вимірявши в окремих дослідах залежності роботи виходу від ступеня покриття для чистих чи змішаних плівок відомого складу, перерахувати двовимірні розподіли локальних значень роботи виходу $\phi(x, y)$ у відповідні розподіли ступеня покриття $\theta(x, y)$.

Використовуючи сильну відмінність параметрів поверхневої дифузії літію та стронцію на грані W(112) (при незанадто високих температурах рухливість адатомів літію набагато вища, ніж у адатомів стронцію $[1,2])$, легко вибрати такий температурний інтервал, у якому можна знехтувати дифузією стронцію у бінарній субмоношаровій плівці Li-Sr. Фактично в таких умовах атоми стронцію виступають як точкові дефекти-стопори для дифузії літію. Концентрацію таких дефектів легко задавати дозою напилення Sr. Суттєво підкреслити, що атомний рельєф грані W(112) різко анізотропний (рис. 1) і в результаті дифузія адатомів відбувається з набагато більшою швидкістю уздовж щільновпакованих атомних борозенок. Наші експерименти виконувалися в такій геометрії, що спостерігався процес дифузії літію саме уздовж борозенок (див. нижче). У таких умовах атоми літію змушені "прицільно" рухатися на дефекти, які також розташовані в борозенках, і тому вплив дефектів може виявитися особливо сильно (рис. 1).

Адсорбуючись на грані (112) вольфраму, літій i стронцій утворюють однотипні довгоперіодні структури $p(1 \times N)(N-$ ціле число), орієнтовані уздовж напрямку [110], тобто перпендикулярно атомним борозенкам підкладки (рис. 1). Термічна стійкість цих структур у стронцію вища, ніж у літію $[8,9]$. Відзначимо, що дифузію вивчали при таких температурах, коли далекий порядок в адсорбованих плівках $\mathrm{Li}$ i $\mathrm{Sr}$ уже був відсутній, але близький ще міг зберігатися.

Для проведення дифузійних експериментів у бінарних $\mathrm{Li}-\mathrm{Sr}$ плівках усю поверхню кристала спочатку рівномірно покривали фоновою плівкою стронцію 3 деяким фіксованим покриттям 


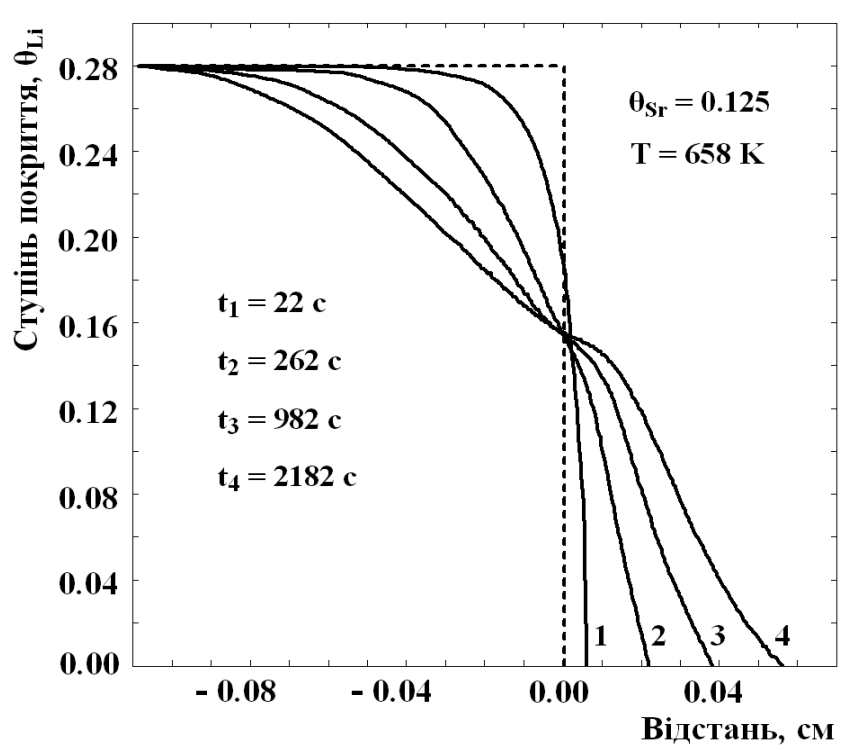

Рис. 2. Концентраційні профілі літію, одержані у процесі дифузійної еволюції на п'єдесталі зі стронцію при $\theta_{\mathrm{Sr}}^{\mathrm{fix}}=0,125$. Край сходинки, показаної пунктиром, відповідає лінії Матано

$\theta_{\mathrm{Sr}}^{\mathrm{fix}}-$ створювався стронцієвий концентраційний "п'єдестал". Після цього на половину підготовленої в такий спосіб поверхні кристала напилювали плівку літію 3 різкою границею, перпендику-

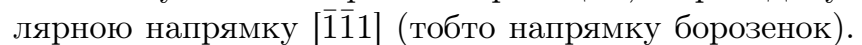
Так створювалася концентраційна "сходинка" літію (рис. 1). Розподіли локальних значень роботи виходу $(x, y)$, отримані в результаті дифузіі літію зі сходинкоподібних початкових покриттів при різних температурах і фіксованих покриттях стронцію, перераховувалися в концентраційні профілі. Для одержання концентраційних залежностей коефіцієнтів дифузії використано метод БольцманаМатано [10]. Таким чином, експериментально визначалися так звані хімічні коефіцієнти дифузії літію на поверхні W(112), попередньо покритій деякою заданою (субмоношаровою) кількістю стронцію.

Температурні інтервали, у яких проводили дифузійні експерименти, лімітувалися двома факторами. 3 боку високих температур обмеження виникали внаслідок необхідності використовувати короткі інтервали часу проведення дифузійного відпалювання (кілька секунд), близькі до часу розігрівання зразка. При низьких температурах час дифузійного відпалювання зростає до декількох годин. Тому виникає небезпека забруднення адсорбованої плівки залишковими газами.

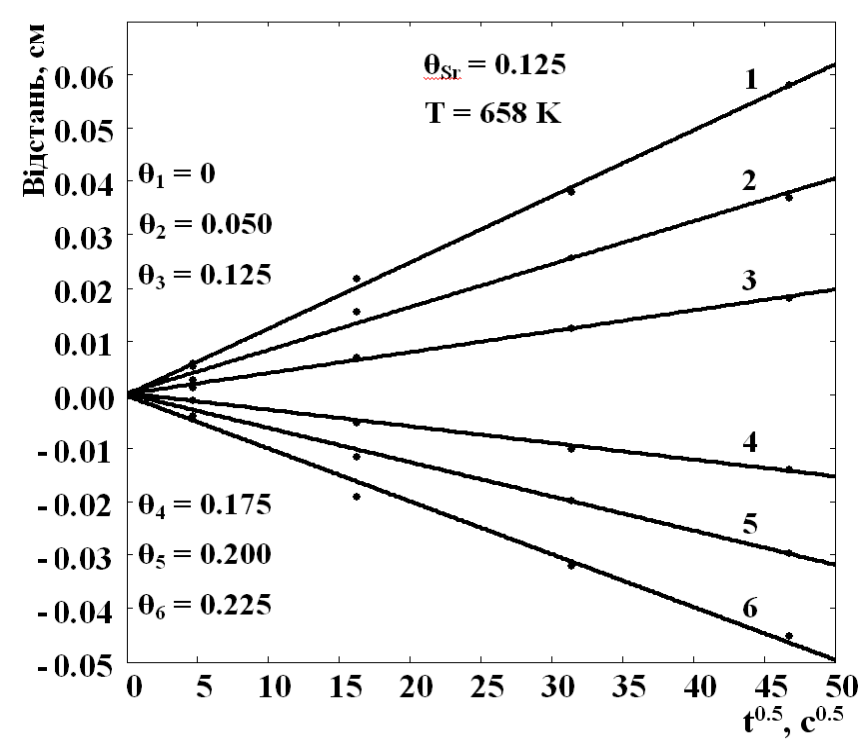

Рис. 3. Залежності зміщення фронту концентраційних розподілів літію у співадсорбованій плівці $\mathrm{Li}-\mathrm{Sr}-\mathrm{W}(112)$ від $t^{0,5}$ при різних покриттях. Лінії побудовано за результатами, наведеними на рис. 2

\section{3. Результати експерименту та їх обговорення}

\section{1. Форма дифузійних профілів концентрації та їх часова еволючія}

Для прикладу на рис. 2 наведено концентраційні розподіли літію в дифузійній зоні при фоновій концентрації стронцію $\theta_{\mathrm{Sr}}^{\mathrm{fix}} \approx 0,125$. Їхня форма явно відрізняється від класичної форми дифузійного розподілу невзаємодіючих частинок, що свідчить про наявність сильної концентраційної залежності коефіцієнтів дифузї літію. Тут важливо з'ясувати, чи буде при цьому дифузійна зона розпливатися за законом $t^{0,5}$, оскільки застосування методу БольцманаМатано для визначення коефіцієнтів дифузії $є$ правомірним лише при виконанні цієї умови. В іншому випадку коефіцієнти дифузії будуть залежними від часу або/і координати, тобто дифузія виявиться аномальною.

Як випливає з рис. 3, еволюція дифузійних розподілів літію відбувається практично за „нормальним“ сценарієм, тобто профілі із прийнятною точністю $є$ інваріантними в координатах $\left(x / t^{0,5}, \theta\right)$. Це дає право використовувати метод Больцмана-Матано для розрахунків концентраційних залежностей коефіцієнта дифузії за формою дифузійних профілів. Метод передбачає обчислення похідної $d \theta / d x$ за експериментально одержаними локальними значеннями роботи виходу, перерахованими у покриття. Існує де- 


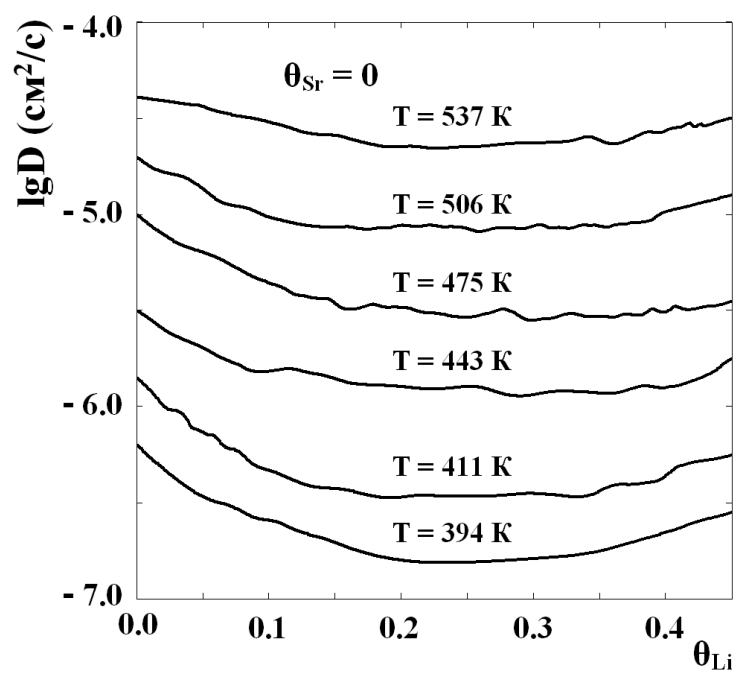

Рис. 4. Залежності коефіцієнтів дифузії літію від ступеня покриття $\theta_{\mathrm{Li}}$ у системі $\mathrm{Li}-\mathrm{W}(112)$. Температури, для яких одержано залежності, показано на рисунку

який розкид величин $\theta$ (шуми), що визначаються 3 експерименту. Це викликано дефектами поверхні підкладки й флуктуаціями самої роботи виходу. Тому без попереднього згладжування розподілів $\theta(x)$ процедуру диференціювання виконати неможливо. Після заміни експериментально отриманих профілів $\theta$ аналітичними функціями (сплайнами) крок диференціювання й інтегрування можна вибирати довільно.

\section{2. Вплив співадсорбованого стронцію на коефіцієнти дифузії літію}

На рис. 4 і 5 наведено отримані при різних температурах концентраційні залежності коефіцієнта дифузіі літію $D$ на чистій поверхні $\mathrm{W}(112)$ і на цій же поверхні, попередньо покритій стронцієм при $\theta_{\mathrm{Sr}}^{\mathrm{fix}}=0,05$. Порівняння цих результатів показує, що навіть невелика кількість атомів стронцію в адсорбційній системі $\mathrm{Li}-\mathrm{Sr}-\mathrm{W}(112)$ не тільки сильно знижує коефіцієнти дифузії літію (приблизно на два порядки величини при однакових температурах), а й приводить до помітних якісних змін концентраційних залежностей $D$. При високих температурах і покриттях $\theta_{\mathrm{Li}}<0,5$ у чистій плівці літію коефіцієнти дифузії досить слабко залежать від концентрації (рис. 4). Зі зниженням температури ця залежність підсилюється, широкий мінімум звужується й локалізується в інтервалі $0,2<\theta_{\mathrm{Li}}<0,3$. Інша картина спостерігається у співадсорбованій плівці. На рис. 5 показано залежності $\lg D\left(\theta_{\mathrm{Li}}, \theta_{\mathrm{Sr}}^{\mathrm{fix}}\right)$, отримані при фіксованому значенні ступеня покриття $\theta_{\mathrm{Sr}}^{\mathrm{fix}} \approx 0,05$. На них при всіх тем-

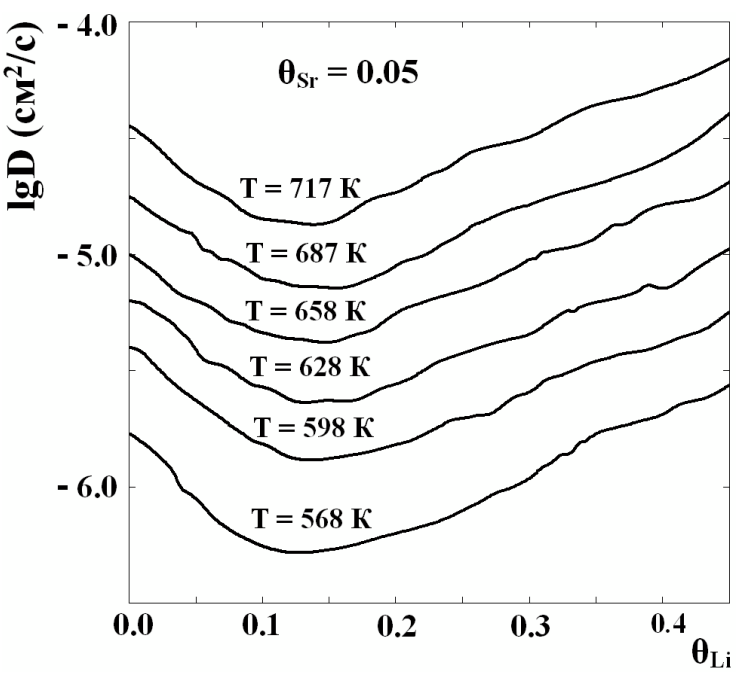

Рис. 5. Залежності коефіцієнтів дифузії літію від ступеня покриття $\theta_{\mathrm{Li}}$ у системі $\mathrm{Li}-\mathrm{Sr}-\mathrm{W}(112), \theta_{\mathrm{Sr}}^{\mathrm{fix}}=0,05$

пературах в області $0,12<\theta_{\mathrm{Li}}<0,15$ чітко проявляються мінімуми, за якими іде сильний (експонентний) ріст коефіцієнтів дифузії: зі збільшенням $\theta_{\mathrm{Li}}$ значення $\lg D$ зростають практично лінійно. Подібний характер росту властивий й для чистої плівки літію, але для неї такий ефект спостерігається при значно вищих покриттях $\left(\theta_{\mathrm{Li}}>0,5\right)[2]$.

Усі ці відмінності в дифузії літію в чистих та співадсорбованих плівках можуть бути викликані зміною не тільки латеральної взаємодії, а також фазового стану плівки й механізмів поверхневої дифузії. Слабка концентраційна залежність коефіцієнтів дифузії у плівках чистого літію при $\theta_{\mathrm{Li}}<0,5$ зумовлена, очевидно, тим, що вибраний для досліджень дифузії температурний інтервал перебуває значно вище критичної температури, і плівка в таких умовах є гомогенною (двовимірний газ, властивості якого з ростом температури наближаються до ідеального газу). Однак при зниженні температури й збільшенні ступеня покриття роль латеральної взаємодії адатомів літію зростає, як і повинно бути у випадку реального газу, що впливає на характер залежностей $\lg D\left(\theta_{\mathrm{Li}}\right)$ (рис. 4).

Дифузія літію і стронцію в чистих плівках на атомно-анізотропній грані (112) вольфраму й молібдену при досить низьких температурах відбувається в результаті руху адатомів уздовж атомних борозенок підкладки, тобто є квазіодновимірною $[11,12]$. Ця обставина зумовлена високими потенційними бар'єрами для руху адатомів впоперек борозенок. При співадсорбції сильно пов'язані з підкладкою адато- 


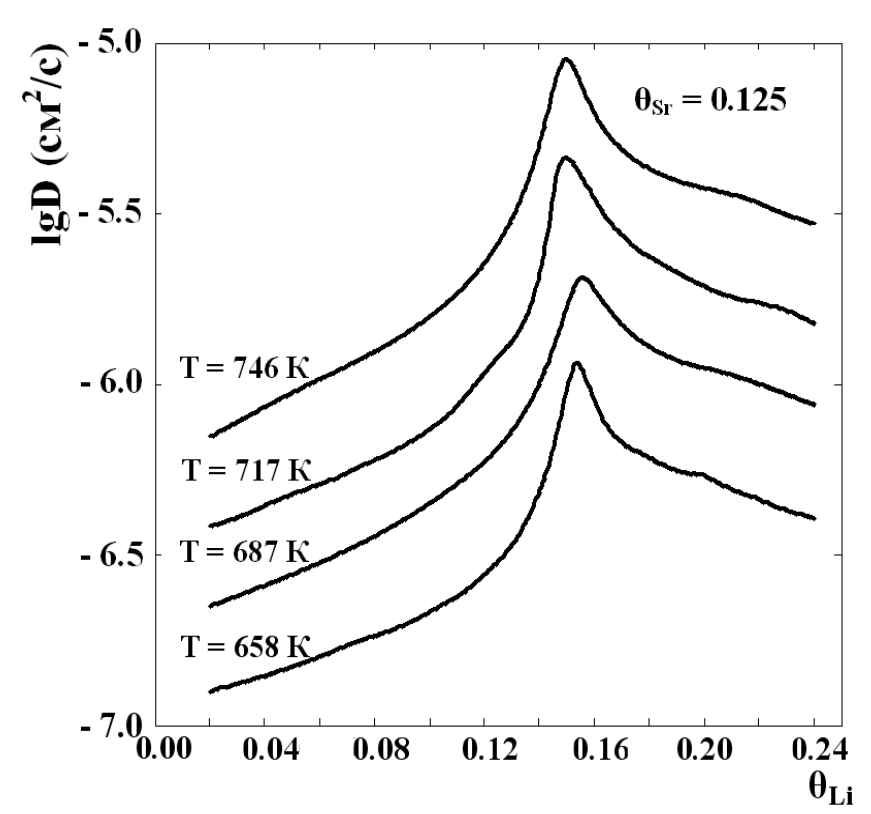

Рис. 6. Залежності коефіцієнтів дифузіі літію від ступеня покриття $\theta_{\mathrm{Li}}$, одержані при $\theta_{\mathrm{Sr}}^{\mathrm{fix}}=0,125$

ми стронцію (енергія адсорбції $\approx 3,6$ еВ) перекривають борозенки й у такий спосіб блокують дифузію літію (рис. 1). Тому для одержання концентраційних профілів макроскопічних розмірів доводиться підвищувати температуру. Очевидно, у таких умовах при низьких покриттях $\theta_{\mathrm{Li}}$ окремі атоми літію можуть обходити атоми стронцію, піднімаючись на "гребені" або навіть переміщуючись у сусідню борозенку, що, природно, вимагає більшої енергї активації. При $\theta_{\mathrm{Sr}}^{\mathrm{fix}} \approx 0,125$ характер концентраційних залежностей коефіцієнтів дифузії радикально змінюється. На рис. 6 показано такі залежності, отримані для різних температур. Як уже зазначалося, при малих кількостях стронцію $\left(\theta_{\mathrm{Sr}}^{\mathrm{fix}} \leq 0,05\right)$ мінімум $\lg D\left(\theta_{\mathrm{Li}}\right)$ звужується й зміщується у бік низьких покриттів літію, а глибина його зростає. Однак при $\theta_{\mathrm{Li}}^{\mathrm{fix}} \approx 0,125$ мінімум $D$ взагалі зникає. У цих умовах на графіках $\lg D\left(\theta_{\mathrm{Li}}, \theta_{\mathrm{Sr}}^{\mathrm{fix}}\right)$ є тільки ділянка майже лінійного зростання $\lg D$ при $\theta_{\mathrm{Li}}<0,1$, а далі ріст стає надлінійним і при $\theta_{\mathrm{Li}}=0,155$ з'являється нова особливість у вигляді сильно вираженого максимуму. Можливу причину таких змін обговоримо в розд. 3.4.

\section{3. Енергї активації та передекспонентні множсники в рівнянні Арреніуса для дифузї літію}

Графіки Арреніуса $\lg D=f(1 / T)$, побудовані для чистої адсорбційної системи Li-W(112), а також при

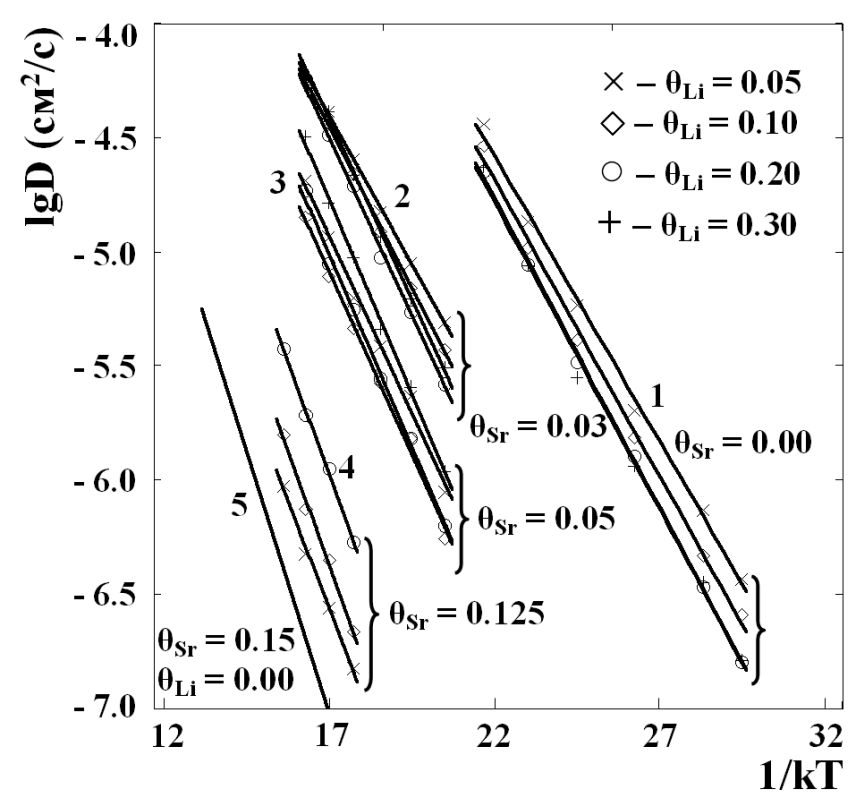

Рис. 7. Графіки Арреніуса для коефіцієнтів дифузіі, побудовані для п'яти адсорбційних систем: 1 - Li-W(112); 2 - Li-Sr$\mathrm{W}(112), \theta_{\mathrm{Sr}}=0,03 ; 3-\mathrm{Li}-\mathrm{Sr}-\mathrm{W}(112), \theta_{\mathrm{Sr}}=0,05 ; 4-\mathrm{Li}-\mathrm{Sr}-$ $\mathrm{W}(112), \theta_{\mathrm{Sr}}=0,125 ; 5-\mathrm{Sr}-\mathrm{W}(112), \theta_{\mathrm{Sr}}=0,15$

наявності стронцію в концентраціях, що відповідають $\theta_{\mathrm{Sr}}^{\mathrm{fix}}=0,03 ; 0,05$ i 0,125 , показано на рис. 7 . На рисунку показано групи ліній при цих покриттях, що відповідають літієвим покриттям $\theta_{\mathrm{Li}}=0,05 ; 0,1 ; 0,2$ і 0,3 . Пряма 5 показує температурну залежність коефіцієнта дифузії стронцію в чистій системі $\mathrm{Sr}-\mathrm{W}(112)$ при $\theta_{\mathrm{Sr}} \approx 0,15$. Експериментальні точки цілком задовільно розташовуються на прямих лініях, що дозволило визначити енергію активації дифузії $E_{d}$ і передекспонентні множники $D_{0}$.

Концентраційні залежності енергї активації для п'яти адсорбційних систем наведено на рис. 8. Криві 1 і 5 відповідають чистим плівкам літію та стронцію на грані (112) вольфраму. Криві 2, 3 і 4 стосуються бінарних плівок, у яких вміст стронцію відповідає покриттям 0,03, 0,05 і 0,125. Як видно, з ростом кількості стронцію в співадсорбованій плівці спостерігається зростання енергії активації. На всіх графіках максимальні значення енергії активації спостерігаються при покриттях $\theta \approx 0,25-0,35$, де $\theta=\theta_{\mathrm{Li}}+\theta_{\mathrm{Sr}}$ є загальним ступенем покриття. Середні величини помилок при визначенні $E_{d}$ зазначено на рисунку у вигляді "вусів". Цікава особливість спостерігається на кривій 4 при $\theta_{\mathrm{Li}} \approx 0,155(\theta \approx 0,28)$. Тут максимум $E_{d}$ виражений досить сильно й корелює 3 максимумами на концентраційних залежностях коефіцієнтів дифузії літію при $\theta_{\mathrm{Sr}}^{\mathrm{fix}} \approx 0,125$ (рис. 6 ). 3 ростом температу- 


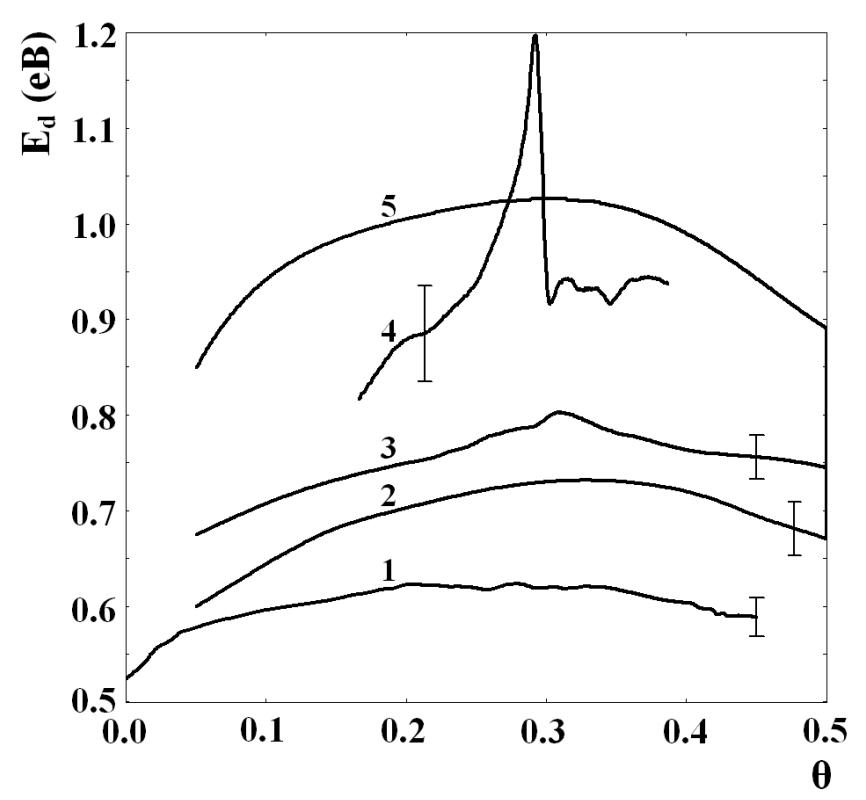

Рис. 8. Залежності енергії активації від загального ступеня покриття $\theta=\theta_{\mathrm{Li}}+\theta_{\mathrm{Sr}}$ для п'яти адсорбційних систем: 1 $\mathrm{Li}-\mathrm{W}(112) ; 2-\mathrm{Li}-\mathrm{Sr}-\mathrm{W}(112), \theta_{\mathrm{Sr}}=0,03 ; 3-\mathrm{Li}-\mathrm{Sr}-\mathrm{W}(112)$, $\theta_{\mathrm{Sr}}=0,05 ; 4-\mathrm{Li}-\mathrm{Sr}-\mathrm{W}(112), \theta_{\mathrm{Sr}}=0,125 ; 5-\mathrm{Sr}-\mathrm{W}(112)$

ри значення покриттів, при яких на дифузійних профілях з'являються перегини, трохи дрейфують у бік низьких концентрацій літію. Крім того, на положення максимумів коефіцієнтів дифузії впливають похибки, які допускалися під час напилення стронцію $\theta_{\mathrm{Sr}}^{\mathrm{fix}} \approx 0,125$ у різних експериментах. Тому точність визначення значень енергї активації в області існування максимуму $E_{d}(\theta)$ становить приблизно $\pm 0,15 \mathrm{eB}$, що помітно нижче, ніж на інших ділянках $( \pm 0,05 \mathrm{eB})$.

На рис. 9 показано концентраційні залежності для передекспонентних множників $D_{0}$. Криві 1 і 5 належать до чистих систем Li-W(112) i Sr-W(112). Вони якісно подібні між собою. Криві 2, 3 і 4 відповідають співадсорбованим системам, у яких $\theta_{\mathrm{Sr}}^{\mathrm{fix}}$ дорівнюють 0,03; 0,05 і 0,125. Як видно, при змішуванні Li i Sr залежності $\lg D_{0}\left(\theta_{\mathrm{Li}}, \theta_{\mathrm{Sr}}^{\mathrm{fix}}\right)$ суттєво змінюються - зокрема відбувається значне зменшення $D_{0}$ при низьких покриттях літію. Це може бути пов'язано зі зміною ентропійного фактора 3 ростом $\theta_{\mathrm{Sr}}$, оскільки адатоми стронцію обмежують число ступенів вільності літію й у результаті зміна ентропії активації $\Delta S$ буде негативною. До того ж наявність стопорів на поверхні буде приводити до зменшення ймовірності здійснення довгих стрибків атомами літію [14].

На кривих 2-4 (рис. 8 і 9) в області загальних покриттів $0,25<\theta<0,35$ вимальовуються максимуми величин $E_{d}$ і $D_{0}$. У випадку $\theta_{\mathrm{Sr}}^{\mathrm{fix}}=0,03$ й 0,05 (кри-

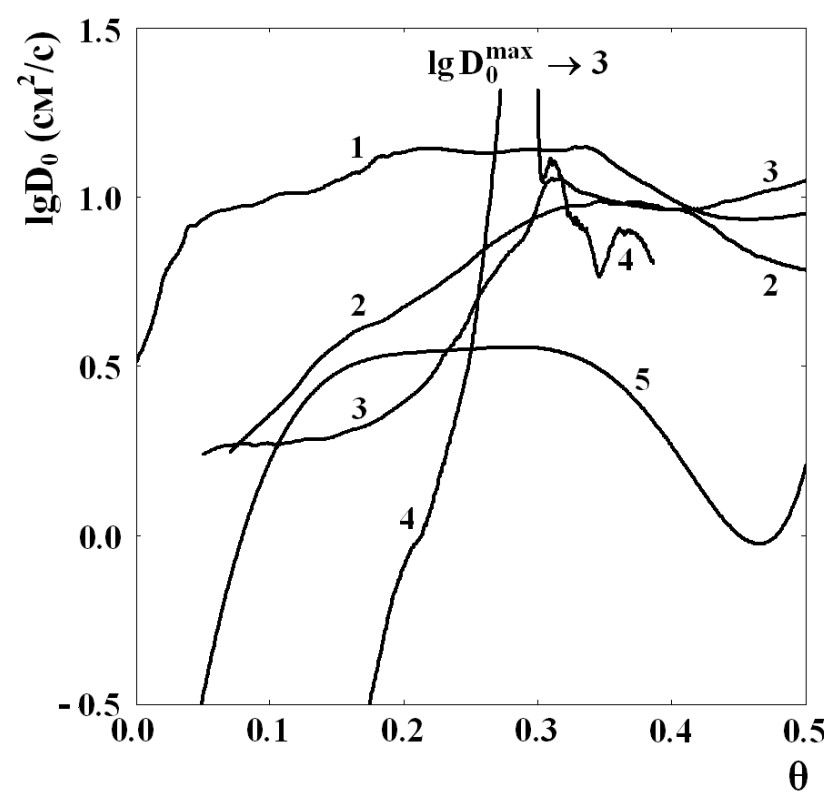

Рис. 9. Залежності передекспонентного множника у рівнянні Арреніуса від загального ступеня покриття $\theta$. Цифрові позначення ліній відповідають прийнятим на рис. 8

ві 2 і 3) це проявляється відносно слабко, але при $\theta_{\mathrm{Sr}}^{\mathrm{fix}} \approx 0,125$ максимуми стають дуже різкими (криві 4). На рис. 9 цей максимум обрізаний, але показано, що значення $\lg D_{0}^{\max }$ наближається до трьох. Взагалі в порівнянні із чистою плівкою літію в змішаних $\mathrm{Li}-$ Sr плівках при збільшенні вмісту стронцію ділянка експонентного росту коефіцієнта дифузії літію зміщується у бік низьких покриттів (див. рис. 4-6). Цей ефект найімовірніше пов'язаний зі змінами характеру взаємодії адатомів і структури плівки, які можуть викликати зміну механізму дифузії. Розглянемо це питання, спираючись на результати наших попередніх робіт.

\section{4. Про зв'язок дифузійних параметрів зі структурою адсорбованих плівок Li $\mathrm{i}$ Sr}

Нагадаємо деякі відомості про структури двовимірних плівок літію та стронцію на грані (112) вольфраму, отримані в роботах $[8,9]$ методом дифракції повільних електронів. Факт утворення в адсорбованих плівках літію й стронцію на W(112) довгоперіодних ланцюжкових надструктур $\mathrm{p}(1 \times 4)$ i $\mathrm{p}(1 \times 7)$ свідчить про те, що сили взаємодії між цими адатомами в напрямку [1ํ1], тобто уздовж борозенок, спадають повільно й немонотонно [15]. Такі структури є сумірними з підкладкою, оскільки їхні періоди кратні періодам поверхневої гратки підкладки. При зростанні 
концентрації взаємодія адатомів посилюється, і вони мінімізують вільну енергію, утворюючи шляхом фазового переходу 1-го роду нові, більш щільні фази. Саме такий процес відбувається у плівках літію й стронцію при $\theta<0,5[8,9]$. Подальше ущільнення плівок при збільшенні $\theta$ відбувається у результаті фазового переходу 2-го роду, тобто порушення структурної сумірності плівок з підкладкою (C-Hперехід). На його початковому етапі сумірність руйнується локально, зосереджуючись у доменних стінках (дислокаціях невідповідності) між сумірними доменами. Вони володіють властивостями і топологічних солітонів, характеризуються високою рухливістю й слугують ефективними переносниками маси в процесі дифузії крізь сумірну фазу [16]. У чистих плівках літію й стронцію на W(112) це відбувається при $\theta>0,5[8,9]$, причому внаслідок сильної анізотропії атомного рельєфу підкладки порушення сумірності відбувається тільки уздовж борозенок (тобто у напрямку [1̄11]).

Наявність у літію й стронцію властивостей, що проявляються за низьких температур в утворенні однотипних довгоперіодних ланцюжкових структур на гранях (112) вольфраму й молібдену, наводить на думку про те, що ці властивості зберігаються й у співадсорбованих плівках. Хоча їх структура у прямих експериментах дотепер не досліджена, можна з високим ступенем імовірності припустити, що на поверхнях з різко анізотропною структурою симетрія грані й анізотропія латеральної взаємодії будуть впливати на характер теплових флуктуацій і розташування адатомів навіть при досить високих температуpax, коли далекий порядок уже порушений. Однак орієнтаційний порядок, за якого адатоми розташовуються в борозенках підкладки й існують фрагменти ланцюжків різної довжини (лінійні кластери), орієнтовані перпендикулярно борозенкам, буде, очевидно, зберігатися (рис. 1). Рівень їх узгодженості з підкладкою знижується з ростом ступеня покриття.

В умовах співадсорбції з літієм атоми стронцію можуть служити центрами зародження бінарних лінійних кластерів, що складаються із атомів літію й стронцію. При високих температурах такі кластери будуть динамічними - вони деформуються, розпадаються й утворюються знову, здійснюють випадкові блукання й дифундують під дією градієнта хімічного потенціалу. Характер латеральної взаємодії змінюється при зміні сумарного ступеня покриття й відносної концентрації компонентів плівки. При зниженні температури кластери можуть розростатися у вигляді ланцюжків різної довжини, орієнтованих пер- пендикулярно борозенкам підкладки (рис. 1). Більш масивні атоми стронцію $\left(m_{\mathrm{Sr}} / m_{\mathrm{Li}} \approx 13\right)$, що мають значну ковалентну складову хімічного зв'язку, будуть гальмувати дифузію кластерів. Припущення про утворення "гібридних" ланцюжків Li-Sr грунтується на результатах узагальнень, виконаних в [16]. Ланцюжки лужноземельних атомів значно стійкіші за лужні. Це запобігає розсипанню ланцюжків внаслідок кулонівського відштовхування сильно поляризованих адатомів. В остаточному підсумку при збільшенні концентрації попередньо адсорбованого стронцію коефіцієнт дифузії літію практично зрівнюється 3 коефіцієнтом дифузії чистого стронцію [6]. Іншими словами, у цих умовах стронцій майже повністю "нав'язуе" свою рухливість усій бінарній плівці. Це демонструють результати, наведені на рис. 4-7 (більш докладні дані про дифузію $\mathrm{Sr}$ на $\mathrm{W}(112)$ див. у роботі [2]).

Обговоримо тепер можливі причини появи різкого максимуму $D_{\mathrm{Li}}$ при $\theta_{\mathrm{Li}}=0,155 \mathrm{i} \theta_{\mathrm{Sr}}=0,125$ (рис. 6). Наявність подібних піків $D$ було виявлено для цілого ряду однокомпонентних адплівок в області C-Hпереходу $[5,6]$ і пояснено на основі солітонної теорії дифузії [16]. У різке збільшення $D$ можуть вносити внесок як термодинамічний фактор (різкий стрибок хімічного потенціалу), так і кінетичний фактор - зміна самого механізму дифузії $[16,17]$. Наприклад, може відбуватися перехід від "одночастинкового" до вираженого колективного механізму дифузії, при якому сильно зростає рухливість переносників маси. Як уже зазначалося вище, такими переносниками можуть бути солітони (несумірні доменні стінки). Енергія активації дифузії в таких умовах визначається рельєфом Пайерлса [16]. Однак на реальній поверхні може відбуватися пінінг солітонів як на власних дефектах підкладки, так і на міцно зв'язаних з нею співадсорбованих атомах (у нашому випадку - адатомах стронцію). Для зриву солітона з дефекту потрібна деяка енергія активації. При цьому передекспонентний множник $з$ ростом концентрації дефектів повинен зменшуватися, що й спостерігається при $\theta<0,25$ (рис. 9). Якщо ж загальне покриття $\theta>0,3$, то при всіх розглянутих $\theta_{\mathrm{Sr}}^{\mathrm{fix}}$ значення $D_{0}$ залишаються досить близькими до тих, які відповідають чистому літію. Однак в області $0,25<\theta<0,3$ i $\theta_{\mathrm{Sr}}^{\mathrm{fix}}=0,125$ ситуація докорінно відрізняється. Це проявляється в стрімкому зростанні у досить вузькому діапазоні концентрацій коефіцієнтів дифузії й передекспонентного множника на фоні значного росту енергії активації. 3 рис. 6 випливає, що при $\theta_{\mathrm{Li}}=0,155$ коефіцієнт дифузії літію $€$ приблизно в 12 раз вищим, ніж при $\theta_{\mathrm{Li}} \rightarrow 0$. Цей мак- 
симум досягається в ситуації, коли сумарний ступінь покриття становить $\theta=0,28$. Можна припустити, що за таких умов у бінарній плівці також починається CН-перехід або при високих температурах принаймні утворюються сумірні (солітонні) конфігурації. Очевидно, у процесі дифузійних переміщень у такій плівці вже беруть участь і атоми стронцію. Дійсно, у розглянутій області покриттів після швидкої десорбції літію в дифузійній зоні виявляється деякий перерозподіл стронцію, що вказує на участь стронцію у процесі вирівнювання хімічного потенціалу на поверхні. Цікаво відзначити, що прискорення дифузіі спостерігається при збільшенні енергії активації (рис. 8), що є можливим тільки при одночасному сильному зростанні передекспонентного множника (рис. 9).

\section{4. Висновки}

Результати, отримані в цій роботі при дослідженні системи Li-Sr-W(112) у широкому інтервалі субмоношарових покриттів, разом з результатами наших попередніх експериментів з іншими подібними системами дозволяють зробити узагальнюючий висновок про сильний вплив малорухомих адсорбованих частинок на кінетику дифузії більш рухливих співадсорбованих з ними частинок. Цей вплив зумовлений взаємодією між співадсорбованими частинками, особливо коли латеральні сили мають далекодійний характер, та колективними механізмами поверхневої дифузії $[6,18]$. При малих ступенях покриття і відштовхувальній взаємодії частинки, що дифундують, мають можливість обходити малорухомі стопори, а у випадку притягувальної взаємодії - нейтралізувати їх, наприклад, заповнюючи дефекти типу пасток. При зростанні ступеня покриття, коли механізми поверхневої дифузії набувають особливо сильно вираженого колективного характеру (наприклад, при фазовому переході, що порушує структурну сумірність плівки з підкладкою), малорухомі домішки у плівці можуть викликати пінінг переносників маси, що охоплює значні ділянки плівки. У розглянутих ефектах важливу роль відіграє атомна структура підкладки. Ця роль особливо велика, коли структура поверхні анізотропна і на ній є атомарні канали, які служать шляхами „легкої“ дифузї. У такому випадку блокування каналів малорухомими домішками виникає сильне сповільнення дифузійних процесів.

Закономірності впливу співадсорбованих домішок на поверхневу дифузію у плівці можуть бути використані для цілеспрямованого модифікування фізико-хімічних властивостей поверхонь.

Дослідження проведено у межах науково-дослідної роботи, профінансованої Міністерством освіти й науки, молоді й спорту України (державний реєстраційний номер 0110U002256) та в рамках проектів B-130 і ОЦ-138, профінансованих Національною академією наук України.

1. A.T. Loburets, A.G. Naumovets, N.B. Senenko, and Yu.S. Vedula, Zeitsch. fur Phys. Chem. 202, 75 (1997).

2. A.T. Loburets, N.B. Senenko, Yu.S. Vedula, and A.G. Naumovets, Ukr. J. Phys. 50, 805 (2005).

3. A.T. Loburets, N.B. Senenko, M.A. Mukhtarov, Yu.S. Vedula, and A.G. Naumovets, Defect and Diffusion Forum 277, 201 (2008).

4. А.T. Loburets, Металлофиз. и нов. технол. 21, 43 (1999).

5. A.T. Loburets, N.B. Senenko, Yu.S. Vedula, and A.G. Naumovets, Atomistic Aspects of Epitaxial Growth, edited by M. Kotrla (Kluwer, Dordrecht, 2002), p. 1.

6. A.G. Naumovets, Physica A 357, 189 (2005).

7. A.G. Naumovets and Yu.S. Vedula, Surf. Sci. Rep. 4, 365 (1984).

8. В.К. Медведев, А.И. Якивчук, УФЖ 20, 1900 (1975).

9. V.K. Medvedev, A.G. Naumovets and T.P. Smereka, Surf. Sci. 34, 368 (1973).

10. J. Philibert, Atom Movements. Diffusion and Mass Transport in Solids (Les Editions des Physique, Les Ulis, 1991).

11. T. Biernat, Ch. Kleint, and R. Meclewski, Applied Surf. Sci. 67, 206 (1993).

12. A.G. Naumovets, M.V. Paliy, Yu.S. Vedula, A.T. Loburets, and N.B. Senenko, Progr. in Surf. Sci. 48, 59 (1995).

13. A.T. Loburets, N.B. Senenko, A.G. Naumovets, and Yu.S. Vedula, Phys. Low-Dim. Struct. 10/11, 49 (1995).

14. O.M. Braun and R. Ferrando, Phys. Rev. E 65, 061107 (2002).

15. О.М. Браун, В.К. Медведев, УФН 157, 631 (1989).

16. I.F. Lyuksyutov, A.G. Naumovets, and V.L. Pokrovsky, Two-Dimensional Crystals (Academic Press, Boston, 1992).

17. A.T. Loburets, A.G. Naumovets, and Yu.S. Vedula, Surface Diffusion: Atomistic and Collective Processes, edited by M.C. Tringides (Plenum Press, New York, 1997), p. 509.

18. A.G Naumovets and Zh. Zhang, Surf. Sci. 500, 414 (2002).

Одержано 10.01.12 


\section{ВЛИЯНИЕ СОАДСОРБИРОВАННЫХ АТОМОВ СТРОНЦИЯ НА ПОВЕРХНОСТНУЮ ДИФФУЗИЮ В СУБМОНОСЛОЙНЫХ ПЛЕНКАХ ЛИТИЯ НА ГРАНИ (112) ВОЛЬФРАМА}

\author{
А.Т. Лобуреи, С.А. Заика, А.Г. Наумовеч, \\ $\mathrm{P}$ е $з$ ю м е
}

Методом сканирующей контактно-потенциальной микроскопии изучена поверхностная диффузия лития в субмонослойных соадсорбированных плёнках $\mathrm{Li}-\mathrm{Sr}$ на атомноанизотропной грани (112) вольфрама. Целью работы было исследование влияния сильно связанных и малоподвижных адатомов (Sr) на кинетику диффузии более подвижных адатомов $(\mathrm{Li})$. Установлено, что адатомы стронция сильно подавляют диффузию лития. Получены концентрационные зависимости химических коэффициентов диффузии, энергии активации и предэкспоненциального множителя в уравнении Аррениуса. Рассмотрены возможные механизмы поверхностной диффузии в соадсорбированной плёнке с учётом характера латерального взаимодействия адатомов, приводящего к образованию длиннопериодных цепочечных структур. Сделан вывод о том, что с ростом концентрации лития, когда плёнка становится структурно несоизмеримой с подложкой, включаются коллективные механизмы диффузии, которые обуславливают экспоненциальный рост коэффициента диффузии. Результаты могут быть использованы при разработке технологий модификации физико-химических свойств поверхностей.

\section{INFLUENCE OF COADSORBED STRONTIUM ATOMS ON SURFACE DIFFUSION IN LITHIUM SUBMONOLAYER FILMS ON TUNGSTEN (112) FACE}

\author{
A.T. Loburets $^{1}$, S.A. Zaika ${ }^{1}$, A.G. Naumovets ${ }^{2}$
}

${ }^{1}$ Yu. Kondratyuk Poltava National Technical University

(24, Pershotravnevyi Ave., Poltava 36011, Ukraine; e-mail: anatollob@gmail.com)

${ }^{2}$ Institute of Physics, Nat. Acad. of Sci. of Ukraine (46, Nauka Ave., Kyiv 03680, Ukraine)

S u m m a r y

The surface diffusion of lithium atoms in coadsorbed Li-Sr submonolayers on the atomically anisotropic tungsten (112) face is studied, by using the method of scanning contact-potential microscopy. The influence of strongly bound and less mobile $\mathrm{Sr}$ adatoms on the diffusion kinetics of more mobile $\mathrm{Li}$ atoms is analyzed. Coadsorbed strontium atoms are found to strongly suppress the diffusion of lithium ones. The concentration dependences are obtained for the chemical diffusion coefficients, activation energy, and pre-exponential factor in the Arrhenius equation. Possible mechanisms of surface diffusion in coadsorbed films are considered, by taking the nature of the lateral interaction between adatoms into account, which is responsible for the formation of long-period chain structures. A conclusion is drawn that the collective mechanisms of diffusion, which give rise to the exponential growth of diffusion coefficients, become active as the lithium coverage degree increases so that the film becomes structurally incommensurate with the substrate. The results obtained can be applied to the development of technologies for the modification of physico-chemical properties of surfaces. 